\title{
Analysis on the Current Situation and Advantages of Sino-Vietnamese Cooperation
}

\author{
Di Wu \\ Kunming University of Science and Technology Oxbridge College, Kunming, Yunnan Province, China
}

Keywords: Sino-Vietnamese cooperation; current situation; advantage analysis.

\begin{abstract}
The cooperation within the greater Mekong Sub-region has opened a chapter for the development of China and Southeast Asian countries, and promoted the cooperation between these countries. In recent years, with the continuously development of economy, countries in the greater Mekong Sub-region have further expanded the cooperation in all fields. Lancang River region, located in the lower reaches of the Mekong River, now occupies an important position in the greater Mekong Sub-region. China and Vietnam are essential members in the Mekong-Lancang River sub-region; to judge the success or failure of the Mekong-Lancang cooperation mechanism, the status of Sino-Vietnamese cooperation can be regarded as an important indicator.
\end{abstract}

\section{Introduction}

The exploitation of Mekong River can be traced back to 18th century, when France invaded Vietnam. Then, Vietnam was infringed repeatedly. In the turbulent situation, however, Vietnamese never stopped the exploitation of Mekong River Basin. In 1957, Vietnam, Laos, Thailand and Cambodia established the Mekong River Basin Investigation and Coordination Committee to promote cooperation and further development. The committee did not bring great changes, but it laid a solid foundation for the large-scale development afterwards. In 1992, the original members of the committee, namely Vietnam, Laos, Thailand and Cambodia, together with two newly joined countries, China and Myanmar, held the Lancang-Mekong sub-regional economic cooperation conference at the initiative of Asian Development Bank, and established the greater Mekong sub-regional cooperation mechanism. Among these counties, China and Vietnam are important members of the Lancang-Mekong sub-regional cooperation mechanism; the cooperation between China and Vietnam can effectively promote the economic development of these two countries.

\section{Current Situation of Sino-Vietnamese Cooperation}

The real sense Sino-Vietnamese cooperation began in the 1990s, when both economies are in the period of rapid development. In order to achieve a win-win result, China and Vietnam signed a series of agreements, opened up a new prospect for cooperation. Under the influence of the Lancang-Mekong sub-regional cooperation mechanism, the scale of Sino-Vietnamese cooperation further expanded. After 2003, China replaced Japan and became the largest cooperative partner of Vietnam.

\subsection{Economic and trade cooperation}

Vietnam is bordered by Yunnan and Guangxi; Hekou of Yunnan, as well as Pingxiang and Dongxing of Guangxi, have maintained good trade relations with Vietnam since ancient times. Nowadays, with the regionalization of cooperation between China and Southeast Asian countries, China and Vietnam are linked more closely.

Since the establishment of the cooperation mechanism, the Greater Mekong Sub-region (including the Lancang-Mekong sub-region) has been developing and progressing. Although being hit by the financial turmoil in Southeast Asia, countries in this region (including China and Vietnam) 
maintained relatively steady cooperation and kept the economic and trade development. [1] Since the 21st Century, the scale of economic and trade cooperation between China and Vietnam has continued to increase. The total trade volume between the two countries increased from \$6.74 billion in 2004 to $\$ 26.39$ billion in 2010 . With the average annual growth of $48.59 \%$, the number has tripled in six years. The stable economic development and huge financial markets of China and Vietnam provide favorable conditions for financial service cooperation between the two countries. In the process of financial cooperation, the regional monetary cooperation mechanism and commercial financial institution cooperation mechanism have achieved good results. The People's Bank of China has strengthened regional monetary cooperation with ASEAN countries, including Vietnam, and established a Monetary and Financial Committee. [2] Realizing the cross-border settlement of RMB has become China's working focus in financial cooperation. At the same time, the cooperation between commercial financial institutions in China and Vietnam is gradually expanding. China and Vietnam have carried out financial exchanges in forms of establishing commercial bank branches, agency banks and overseas accounts, to further deepen financial cooperation between the two countries.

\subsection{Cooperation in the field of transportation}

China and Vietnam are bordering; traffic is not a problem in cooperation. But land traffic along the border cannot meet the needs of two countries. Therefore, the importance of traffic cooperation was clearly put forward by Yunnan at the greater Mekong sub-regional cooperation conference and became an important consideration of GMS.

In recent years, [3] great achievements have been made in transportation field of Sino-Vietnamese cooperation. Major projects include Kunming-Bangkok Highway and Trans-Asian Railway construction, the building of airports in China and Vietnam, and the improvement of ports and harbors in two countries. Water, land and air transportation systems in China and Vietnam have been further improved. China has more powerful technologies and more obvious advantages in architecture; Vietnam and China are cooperating more and more closely in architectural services. In recent years, China has contracted most of the construction projects in Vietnam, including power stations, bridges, highways, railways, residences and commercial buildings

\subsection{Cooperation in the field of energy}

As important members of the Lancang-Mekong cooperation system, China and Vietnam attach importance to energy cooperation. With big rivers running through, both countries are rich in water and hydropower resources. Cooperation in hydropower is the key point of cooperation between the two countries.

After a long period of consultation, China and Vietnam signed a memorandum in 2002. The China Southern Power Grid Company Limited and Vietnam Electric Power Bureau reached an agreement to transmit electricity from China Southern Power Grid to eight northern provinces of Vietnam. In 2005, China and Vietnam signed another memorandum. China Southern Power Grid Company would invest the Phase-I project of the construction of a Coal-fired Power Plant in Binh Thuan Province of Vietnam through the model of BOT. The cooperation between China and Vietnam in electric power and energy is lifted to a higher level. So far, the cooperation between China and Vietnam in the field of energy represented by electric power cooperation has been expanding and deepening.

\subsection{Cooperation in tourism}

As a new industry, the importance of tourism in national economy is increasing. Vietnam is rich in tropical rain forest resources, and has a vegetation coverage rate of $43.8 \%$; China has temperate and subtropical climates. Both countries posses various ethnic groups and rich folk customs, which provide a broad space for the development of tourism industry.

Sino-Vietnamese tourism cooperation has a good record. As an indicator of bilateral cooperation, the project of Karst Scenery Tourism along the northeastern border of Vietnam and Guangxi develops well. The project of cross-border river rafting in Gaolin, Guangxi province has operated for many 
years. The large-scale live performance project is also in the plan. Over these years, China and Vietnam have continuously trained high-quality tourism talents, taking tourism as the focus of bilateral development.[4] Since 1996, the number of China-Vietnam tourists has been increasing continuously. Even in 2008, under the influence of global economic recession and domestic inflation of China, the annual growth in number of Chinese tourists who went to Vietnam reached 131\%. Tourism, as an important method of earning foreign exchange, is an indispensable part in Sino-Vietnamese cooperation mechanism.

\subsection{Cooperation in ecological environment}

Environment is supporting the rear of economy. Without good environment, economic development cannot last long. China (Yunnan Province and Guangxi Province) and Vietnam are members of GMS; environmental protection is an important topic in cooperation. The Environment Meeting of GMS Working Group is held annually, in order to actively promote environmental protection in the Lancang-Mekong River Basin. The meeting is highly valued by GMS.

In recent years, [5] GMS Environmental Working Group has carried out a series of cooperation in various fields, including biodiversity conservation, natural resources protection, poverty alleviation, environmental monitoring in river basin and so on. Remarkable results have been achieved. The biodiversity conservation corridor project, as a key project in the field of environmental protection, has received strong support from the Asian Bank, the Swedish International Development Cooperation Agency and the Netherlands. The cooperation between China and Vietnam in environmental protection can provide better conditions for the development of the Lancang-Mekong sub-region.

\section{Advantages in Sino-Vietnamese Cooperation}

\subsection{Geographical convenience}

Yunnan Province of China and Vietnam are adjacent to each other. As early as in the Han Dynasty, Yunnan was the gateway to foreign trade. [6] In the past, highways between China and Vietnam were low density, low standard and of poor quality. The two countries were interested in communication, but objective conditions did not permit. In recent years, China and Vietnam have deepened their cooperation. Frequent trade exchanges make full use of the convenient transportation and border advantages.

According to records, there were seven Ancient Tea Horse roads, including the Yunnan-Vietnam ancient road (from Kunming to Vietnam through the estuary of Red River), which linked up the southern Silk Road between China and Vietnam. It is not difficult for China and Vietnam to combine their regional and historical advantages perfectly and transform the simple trade exchange into multi-faceted cooperation.

As early as 1994, the Greater Mekong Sub-region proposed nine cooperation plans, many of which linked China and Vietnam. [7] Railways (Kunman Railway will improve the existing railway transport capacity from Kunming to Hanoi, Vietnam), highways, waterways and aviation lines are all constructed based on geographic convenience. At the same time, the development of transportation has laid a solid foundation for further cooperation between the two countries. Therefore, China and Vietnam, as important members of the Lancang-Mekong sub-region, should use their geographic advantages in further development.

\subsection{Resource complementation}

Due to differences in production technologies, historical conditions and culture, various economic development patterns gradually appear in different countries. Countries and regions without economic advantages may have relatively unique resources. Although China and Vietnam are adjacent to each other, their climate and geographical conditions are obviously different. Utilizing their respective resource advantages to complement each other is an important part in bilateral 
cooperation.

Yunnan and Guangxi located at the Mekong River Basin. [8] The two provinces have rich in hydropower resources, which ranks sixth in our country. They possess diversified and rich mineral resource reserves, of which lead, zinc and tin are biggest in China. The copper and phosphorus reserves are in excellent qualities; the amount of reserve occupy top positions in China. Moreover, these resources are relatively easy to exploit. At the same time, Yunnan enjoys pleasant climate, diversified ethnic groups and obvious advantages in tourism resources. Vietnam has tropical rain forest climate; the characteristics of tropical rain forests are obvious. The territory of Vietnam is narrow and long, with coastline of more than $3000 \mathrm{~km}$. The water resources of Vietnam ranks 14 in the world. Vietnam is also rich in coal resources as well as oil and gas resources. The scenery of Ha Long Bay of Vietnam is unique to the world.

China and Vietnam have different resources. They should give full play to their advantages in resources and complement each other in forestry, fisheries, oil and gas, mineral resources and tropical economic crops. The resource complementation can help the two countries to change their economic development models into more favorable patterns.

\subsection{The guidance of ASEAN sub-regional cooperation mechanism}

In the late 20th century, the international economic situations changed; the phenomenon of economic regionalization gradually appeared. The success of the North American Free Trade Area (NAFTA) and the European Union led to processes of economic regionalization in other regions. Under that influence of world tendency, ASEAN is also seeking changes and development, and exploring the path of economic cooperation and regional integration.

With its own advantages and economic status, Singapore is the pioneer in seeking small-scale cooperation. The country established links between Johor State, Malaysia and Riau Islands Province, Indonesia. [9] A new triangle development model is formed to make use of their advantages in capital, technology, natural resources and labor force. The model soon becomes a successful example of ASEAN sub-regional economic cooperation and attracts other countries and regions to join in. Singapore's success inspires other Southeast Asian countries; various triangle cooperation patterns are come into being. The scope of cooperation gradually expands from a small scale to the association of Southeast Asian nations. The content of cooperation also expands from single economic cooperation to all-round cooperation. These organizations promote the rapid development of ASEAN.

The success of ASEAN sub-regional cooperation provides favorable guidance and support to the development of ASEAN Mekong region. On that basis, cooperation between countries in the Lancang-Mekong sub-region, including China and Vietnam, can develop continuously.

\section{References}

[1] L Liu, Asian Development Bank: escorting the development of the Greater Mekong Sub-region, J. China Finance. 8 (2010).

[2] J.H. Liu, D. Qi, R. Wang, et al. The short-term pain of Pearl River Delta can benefit China ASEAN for a long run, J. Financial Development Review. 5 (2015) 14-37.

[3] Lancang River: a great international shipping line to prosperity, China Water Transport, Nov. 17, 2009.

[4] Yunnan Tourism Statistical Project, Tourism in Yunnan from January to December 2009

[5] Ministry of Commerce of the People's Republic of China Department of Asian Affairs, Strengthening mutually beneficial cooperation for common prosperity - overview of China's participation in greater Mekong sub-region cooperation, J. China Business Update. 6 (2008).

[6] L.X. Wang, On Resource Conversion: Economic Analysis of Resource Advantage Conversion in West Minority Nationality Areas, China Economic Publishing House, Beijing, 2006. 
[7] X.S. Gu (Eds.), Strategic Conception of Transport Cooperation between China and ASEAN: A Study on Building a Marine, Land and Air Transport Hub in Guangxi, Social Sciences Academic Press (China), Beijing, 2010.

[8] China Society of Territorial Economists, Natural Resources and Economic Advantages of Provinces, Municipalities and Autonomous Regions of China

[9] W.N. Li, Growth of Yangtze River Delta region in north: a beneficial attempt in ASEAN sub-regional economic cooperation, J. China-ASEAN Panorama. 10 (2007). 